\title{
LEGAL PROBLEMS OF DUALISM OF JUDICIAL REVIEW SYSTEM IN INDONESIA
}

\author{
Pan Mohamad Faiz \\ TC Beirne School of Law, the University of Queensland \\ The University of Queensland, St. Lucia Campus, Australia \\ E-mail: pan.wijaya@uq.net.au
}

\begin{abstract}
Indonesia implements dualism of judicial review system because there are two different judicial institutions that are granted the authority to review laws and regulations, namely the Constitutional Court and the Supreme Court. This research aims to analyse the problems caused by the dualism of judicial review system. It found two main legal problems of the current system. First, there is an inconsistency of decisions concerning judicial review cases for the same legal issues decided by the Constitutional Court and the Supreme Court. Second, there is no mechanism to review the constitutionality of People's Consultative Assembly (MPR) decisions and regulations under the level of law. Based on these findings, this research suggests that the authority to review all laws and regulations should be integrated under the jurisdiction of the Constitutional Court.
\end{abstract}

Keywords: Constitutional Court, Constitutional Review, Judicial Review

\begin{abstract}
Abstrak
Indonesia menerapkan dualisme sistem pengujian norma hukum, sebab terdapat dua institusi pengadilan berbeda yang diberikan kewenangan untuk melakukan pengujian peraturan perundang-undangan. Artikel ini bertujuan untuk menganalisa permasalahan yang diakibatkan dari dualisme sistem tersebut. Pertama, adanya inkonsistensi putusan pengujian peraturan perundang-undangan terhadap isu yang sama yang diputuskan oleh Mahkamah Konstitusi dan Mahkamah Agung. Kedua, tidak adanya mekanisme untuk menguji konstitusionalitas Ketetapan MPR dan peraturan di bawah undang-undang. Berdasarkan temuan tersebut, artikel ini menyarankan agar kewenangan untuk menguji seluruh peraturan perundang-undangan sebaiknya diintegrasikan di bawah kewenangan Mahkamah Konstitusi.
\end{abstract}

Kata kunci: Mahkamah Konstitusi, Pengujian Konstitusionalitas, Pengujian Peraturan PerundangUndangan

\section{Introduction}

Judicial review refers to the authority of a court to review the constitutionality of legislative and executive actions. It means that a court can invalidate laws or decisions contrary to higher laws or regulations, particularly the Constitution. The term of judicial review is often used interchangeably with constitutional review. Nevertheless, judicial review has a broader meaning compared than a constitutional review. In this context, judicial review can both examine the constitutional validity of laws and regulations as well as administrative actions and decisions, while constitutional review is more specific to review the constitutionality of laws and regulations.
Judicial review was first exercised by the U.S. Supreme Court in the 1803 case of Marbury vs Madison, ${ }^{1}$ but long before that case, there was a case of judicial review of Dr. Bonham's case decided by the Court of Common Pleas in England in $1610 .^{2}$ There are two main models of judicial review, namely the American model and the European model. The first model is also known as the decentralised model in which the

See William Benoit and J. D. Agostine, "The case of the midnight judges' and Multiple Audience Discourse: Chief Justice Marshall and Marbury v. Madison", The Southern Communication Journal, Vol. 59 No. 2, March 1994, Philadelphia: Taylor \& Francis, pages 89-96.

2 See R. A. Edwards, "Bonham's Case: The Ghost in the Constitutional Machine", Denning Law Journal, Vol. 11 No. 1, 1996, Buckingham: University of Buckingham Press, page 63-90. 
judicial review authority is exercised by the Supreme Court and other lower courts. This model is used in countries such as the United States of America, Australia, Canada, India and the Philippines. The second model is also known as the centralised model or the European model. ${ }^{3}$ This model gives the authority to review the constitutionality of laws to the Constitutional Court as a separate judicial institution from the Supreme Court, as occurs in countries such as Austria, Germany, South Africa, South Korea and Turkey. The innovation in this constitutional system has been influenced by Hans Kelsen (1881-1973). ${ }^{4}$ Therefore, this model is also known as the Kelsenian model. ${ }^{5}$ Indonesian judicial review system follows this Kelsenian model.

The Indonesian Constitution granted authority to review the constitutionality of national laws to the Constitutional Court, whilst the Supreme Court is granted an authority to review the legality of regulations below the level of national law. This mechanism creates a dualism of judicial review system that led to the complexity of the legal system in Indonesia. The question is what are the legal problems caused by the dualism of judicial reviews system adopted in Indonesia? and how can the problems be prevented or solved?

\section{Discussion}

\section{Legal Policy of Judicial Review System}

3 Victor Ferreres Comella, "The European Model of Constitutional Review of Legislation: Toward decentralization?", ICON - International Journal of Constitutional Law, Vol. 2 No. 3, July 2004, New York: Oxford University Press and New York University School of Law, pages 461-491.

4 Hans Kelsen, “Judicial Review of Legislation: A Comparative Study of the Austrian and the American Constitution", Journal of Politics, Vol. 4, May 1942, Chicago: The University of Chicago Press, pages 183-200.

5 See Christoph Bezemek, "A Kelsenian Model of Constitutional Adjudication: The Austrian Constitutional Court", Zeitschrift fur offentliches Recht, Vol. 67, March 2012, Vienna: Springer, pages 115-128; Sara Lagi, "Hans Kelsen and the Austrian Constitutional Court (1918-1929)", Co-herencia, Vol. 9 No. 16, June 2012, Medellín: Universidad EAFIT, pages 273-295; S. AmaralGarcia, N. Garoupa and V. Grembi, "Judicial Independence and Party Politics in the Kelsenian Constitutional Courts: The Case of Portugal", Journal of Emperical Legal Studies, Vol. 6 No. 2, June 2009, New Jersey: Cornell Law School and Wiley Periodicals, pages 381-404.
The development of judicial review in Indonesian judicial system can be divided into three main periods: the Soekarno era from 1945 to 1966; the Soeharto era from 1966 to 1998 and the constitutional reform era from 1998 to present. As explained previously, the current judicial review in Indonesia follows the European or the Centralised model of judicial review. In 1949, however, Indonesia followed the American or the decentralised model of judicial review. In this section, I will discuss the development of legal policy regarding judicial review system in Indonesia by tracing the three different periods mentioned above.

\section{First Period: Soekarno Era (1945-1966)}

Although the mechanism of constitutional review was finally formed after the Constitutional Court establishment in 2003, the discussion and debate about the need for a constitutional review system had occurred in the drafting process of the first Indonesian Constitution, prior to independence in 1945. During a meeting of the Investigating Committee for Preparatory Work for Indonesian Independence (Badan Penyelidik Usaha-Usaha Persiapan Kemerdekaan Indonesia or BPUPKI) in July 1945, one of the constitutional drafters, Muhammad Yamin, proposed that the Supreme Court (Balai Agung) should have a power to review laws not only against the Constitution but also customary law and Islamic law. Yamin used the term of 'comparing' (membanding), which refers to the term of 'reviewing' (menguji). ${ }^{6}$

The proposal delivered by Yamin was challenged by another BPUPKI member, Soepomo, citing two main reasons. The first reason was that Indonesia did not adopt the concept of separation of powers as implemented by other countries. Therefore, the judiciary could not control the other state powers in making laws. According to Soepomo, the issue whether a law was contrary to the Constitution or not was not a judicial matter, but a political matter. He also

6 Saafroedin Bahar et al, 1995, Risalah Sidang Badan Penyelidik Usaha-Usaha Persiapan Kemerdekaan Indonesia (BPUPKI), Panitia Persiapan Kemerdekaan Indonesia (PPKI) 26 Mei 1945 - 22 Agustus 1945, Jakarta: Sekretariat Negara Republik Indonesia, page 295. 
argued that the judicial review system would not be appropriate in the Indonesian context. ${ }^{7}$

The second reason was that Indonesian legal experts did not have much experience in exercising a judicial review system at that time. Soepomo compared Indonesia with Austria, Germany and the Czech Republic that had special courts to deal with constitutional matters. For these reasons, he suggested that Indonesia was not ready to apply the judicial review system. Given that there was no consensus during the meeting, Yamin's proposal to give judicial review power to the Supreme Court was not inserted into the 1945 Constitution. ${ }^{8}$

Furthermore, the 1945 Constitution enacted on 18 August 1945 was replaced by the Constitution of the Republic of the United States of Indonesia or the RIS Constitution (19491950). The provisions contained in the RIS Constitution were strongly influenced by the United States, including the adoption of the American model of judicial review. The RIS Constitution set a judicial review mechanism that authorised the Supreme Court and other ordin-ary courts to review the constitutionality of fe-deral or state laws. ${ }^{9}$ However, the RIS Constitution was applied for less than one year, from 27 December 1949 until 17 August 1950, and there was not a single case handled by the Supreme Court related to judicial review.

Moreover, Indonesia changed the RIS Constitution to 1950 Provisional Constitution (19501959). The 1950 Provisional Constitution was intended to be temporary until a permanent constitution was formed. During the constitutional drafting, the Indonesian Judges Association (IKAHI) suggested that the Supreme Court should have a power to review the constitutionality of legislations. The proposal was discussed in the Constituent Assembly (Konstituante), which had been established based on the results of the 1955 General Elections to form a permanent Constitution. In their discussions, the Constituent Assembly agreed to establish a special

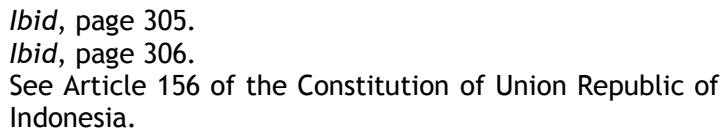

See Article 156 of the Constitution of Union Republic of Indonesia.

court consisting of justices who were authorised to review legislations.

Unfortunately, after conducting the sessions for two and a half years, the Constituent Assembly was unable to complete the main task of forming a permanent Constitution due to a deadlock among its members, particularly on a very sensitive issue related to concepts and relations between state and religion. Consequently, an initial agreement to establish a judicial review system could not be implemented. Given that the Constituent Assembly could not manage to create a new Constitution for replacing the 1950 Provisional Constitution, President Soekarno declared the Presidential Decree of 5 July 1959 to dissolve the Constituent Assembly and to restore the validity of the 1945 Constitution as the permanent Constitution of Indonesia. ${ }^{10}$

\section{Second Period: Soeharto Era (1966-1998)}

Discussions for creating a judicial review system also occurred during the New Order under the Soeharto's administration (1965-1998). Based on Law No. 14 Year 1970 concerning the Judicial Power, the Supreme Court was granted a power of judicial review. ${ }^{11}$ However, the power was limited to review of regulations against laws. The Judicial Power Law did not regulate the mechanism to review the constitutionality of laws. Moreover, the related provisions were amended by Law No. 14 Year 1985 concerning the Supreme Court. Nonetheless, the new provisions asserted that the Supreme Court only had a power to review regulations below national laws against laws only, but not against the Constitution. ${ }^{12}$

The absence of a constitutional review system at that time was caused by the Indonesian constitutional structure that implemented the distribution of a power system. Consequently, it created supremacy of parliament in the People's Consultative Assembly (Majelis Permu-

\footnotetext{
10 See Presidential Decree No. 150 Year 1959 concerning the Decree of the President of the Republic of Indonesia/Supreme Commander of the War Armed Forces Concerning the Return to the 1945 Constitution.

11 Article 26 of the Judicial Power Law.

12 Article 31 of the Supreme Court Law.
} 
syawaratan Rakyat or MPR). In practice, the doctrine meant other branches of government were not allowed to intervene with the legislative branch powers. In addition, the absence of constitutional review mechanisms was considered a deliberate action by Soeharto to maintain power.

Despite this view, Soeharto genuinely and consistently suggested implementing the 1945 Constitution in his speeches. Lacking a state institution with authority to review and interpret the 1945 Constitution, Soeharto held full power in interpreting the laws that perpetuated his authority for 32 years. As a result, there were only 12 cases relating to judicial review after the Supreme Court was given a limited power of judicial review in 1970 until the constitutional reform occurred in $1998 .{ }^{13}$

\section{Third Period: Constitutional Reform (1998- Present)}

Discussion on the need of a constitutional review system re-occurred during the constitutional amendment process in 2000. After discussing the mechanism, the MPR issued Decision No. III/MPR/2000 granting the MPR a power to review the constitutionality of laws. The parliament supremacy doctrine was the main foundation in establishing this mechanism. However, it cannot be categorised as a judicial review mechanism since the power would be exercised by the legislative, not by the judiciary. Thus, this mechanism is best categorised as legislative review, not judicial review. However, the MPR never exercised its power because the system was not clear. Therefore, the MPR members proposed to establish a judicial institution called the Constitutional Court. ${ }^{14}$

The MPR members were divided into two opinions for determining judicial review powers to be granted to the Constitutional Court. The first opinion was that the Constitutional Court

13 See Zainal Arifin Hoesein, 2009, Judicial Review di Mahkamah Agung: Tiga Dekade Pengujian Peraturan Perundang-undangan, Jakarta: RajaGrafindo Persada.

14 For comparative study of constitutional courts establishment, see Francisco R. Romeu, "The Establishment of Constitutional Courts: A Study of 128 Democratic Constitutions", Review of Law \& Economic, Vol. 2 No. 6, August 2006, Berlin: De Gruyter, pages 103-135. should only review the constitutionality of law, while regulations under the national law could only be reviewed by the Supreme Court. The main reason was to avoid practical difficulties related to the high number of laws and regulations directly related to the litigation process handled by the Supreme Court and lower ordinary courts. ${ }^{15}$ The second opinion was that the constitutionality of all laws and regulations should be reviewed by the Constitutional Court. The aim of incorporating this constitutional review mechanism was to obtain consistent considerations and decisions in judicial review cases, as practiced in other countries. ${ }^{16}$

The final decision inserted into the Constitution was that the Constitutional Court could only review the constitutionality of national laws, while the Supreme Court retained the power to review the legality of regulations. Thus, the current judicial review system in Indonesia is embracing the dualism of judicial review system exercised by the Constitutional Court and the Supreme Court. Consequently, the judicial review mechanism becomes more complicated, as I will explain below.

\section{Dualism of Judicial Review System}

In the Indonesian legal system, there exists a hierarchical structure of laws adopted from the pyramid of law theory by Hans Kelsen, known as Stufenbau des Rechts. Presently, the types and hierarchy of laws in Indonesia consist of the 1945 Constitution, People's Consultative Assembly (MPR) Decision, Law or Government Regulation in Lieu of Law (Interim Emergency Law or Perppu), Government Regulation, Presidential Regulation, Provincial Regulation and Regency/City Regulation. The legal power of those laws is in accordance with the hierarchical structure ranging from the highest to the lowest level.

Regarding the judicial review system, Indonesia has two separate mechanisms. The first mechanism is that the Constitutional Court can

\footnotetext{
15 See Majelis Permusyawaratan Rakyat Republik Indonesia, 2008, Risalah Rapat ke-36 Panitia Ad Hoc I, Badan Pekerja MPR, Jakarta: Sekretariat Jenderal MPR RI, pages 340, 344, 434, 436, 531.

16 Ibid, pages 357, 435, 437, 554.
} 
only review the constitutionality of laws enacted by the President and the House of Representative (Dewan Perwakilan Rakyat or DPR). The second mechanism is that only the Supreme Court can review the legality of regulations below the level of law, this includes Government Regulation, Presidential Regulation, Provincial Regulation and Regency/City Regulation. ${ }^{17}$ In my view, this dualism has created at least three legal problems in the constitutional review system in Indonesia.

First, if the Constitutional Court can only review the constitutionality of laws, while the Supreme Court can review regulations against laws, not against the Constitution, no legal mechanism is provided to review regulations or decisions against the Constitution. In other words, there is no mechanism available to review the constitutionality of regulations and decisions under the level of law. For instance, the constitutionality of 365 regional regulations in Indonesia, considered discriminatory by the National Commission on Violence against Women (Komnas Perempuan), cannot be reviewed by the Constitutional Court or the Supreme Court. ${ }^{18}$

Second, the dualism of judicial review system in Indonesia creates an inconsistency of interpretations between laws and the implementing of regulations. For example, the Supreme Court declared Decision Number 15/P/HUM/ 2009 on June $18^{\text {th }} 2009$ concerning judicial review on the National Election Commission Regulation No. 15 Year 2009. Problematically, the Supreme Court gave a different interpretation to the Constitutional Court's previous interpretation for the same case. Consequently, there was an inconsistency of interpretation in deciding the case. In the end, the Constitutional Court had to declare another decision in the Parliamentary Seats Phase III (2009) case to cor-

17 Article $24 \mathrm{~A}$ and Article $24 \mathrm{C}$ of the Indonesian Constitution as well as Article 9 of Law No 12 of 2011 on the Establishment of Laws and Regulations.

18 Ihsanuddin, 20 March 2015, "Komnas Perempuan Minta Presiden Jokowi Hapus 365 Perda yang Diskriminatif", Kompas, available at http://nasional.kompas.com/ $\mathrm{read} / 2015 / 03 / 20 / 11583441 /$ Komnas.Perempuan.Minta. Presiden.Jokowi.Hapus.365.Perda.yang.Diskriminatif, accessed on April $10^{\text {th }} 2016$. rect the Supreme Court's interpretation that caused a national political uproar.

Whereas that in this decision the Constitutional Court did not assess or review either the Supreme Court's decision or the General Election Commission Regulation... However, since Article 205(4), Article 211(3) and Article 212(3) of Law No. 10 Year 2008 has been assessed by the Constitutional Court as conditionally constitutional, then by itself all the contents of regulations or the court decisions which are not in accordance with this decision becomes invalid due to loss of its basis. ${ }^{19}$

After the Constitutional Court declared the decision, indirectly annulling the Supreme Court decision, no institutional conflict occurred between them. However, if such inconsistency of interpretation occurs frequently, then, most likely, conflict or dispute will result between the Supreme Court and the Constitutional Court, as emerged in other countries. ${ }^{20}$ This conflict may occur because the Indonesian Constitutional Court is not granted power to assess or examine the Supreme Court decisions. This system is different from, for instance, the Federal Constitutional Court of Germany which is formally given the power to re-examine the Supreme Court decisions related to fundamental rights violations of citizens using the constitutional complaint mechanism. ${ }^{21}$

19 See Constitutional Court Decision No. 110-111-112-113/ PUU-VII/2009.

20 See Lech Garlicki, "Constitutional Courts versus Supreme Courts", International Journal of Constitutional Law, Vol. 5 No. 1, January 2007, New York: Oxford University Press and New York University School of Law, pages 44-68.

21 For further discussion of constitutional complaint, see Pan Mohamad Faiz, "A Prospect and Challenges for Adopting Constitutional Complaint and Constitutional Question in the Indonesian Constitutional Court", Constitutional Review, Vol. 2 No.1, May 2016, Jakarta: The Constitutional Court of the Republic of Indonesia, page 103-128; Gerhard Dannemann, "Constitutional Complaints: The European Perspective", The International and Comparative Law Quarterly, Vol. 43 No. 1 January 1994, Cambridge: Cambridge University Press, page 142153; Nazlı Can Ülvan, "Constitutional Complaint and Individual Complaint in Turkey", Ankara Bar Review, Vol. 6 No. 2, 2013, Ankara: Ankara Bar Association, pages 179-186; Aušra Kargaudienè, "Individual Constitutional Complaint in Lithuania: Conception and the Legal Issues", Baltic Journal of Law \& Politics, Vol. 4 No. 1, January 2011, Berlin: De Gruyter, page 154-168. 
Third, in the previous judicial review system, the MPR decision was not placed in the hierarchy of laws. ${ }^{22}$ Currently, it is in the hierarchy of laws under the Constitution, but it is above the level of law. As a result, the constitutionality of MPR decisions cannot be reviewed by the Constitutional Court since the Court can only review the constitutionality of laws or interim emergency laws. The absence of this mechanism has been confirmed by the Constitutional Court's decision, stating that the Court does not have a power to review the constitutionality of the MPR decisions. ${ }^{23}$ Thus, the MPR decisions have caused a constitutional problem in the hierarchy of laws because it cannot be reviewed by judicial institutions, neither the Constitutional Court nor the Supreme Court. ${ }^{24}$

Based on the three major problems explained above, I am of the opinion that the constitutional review of all laws and regulations under the Constitution should be integrated into one judicial institution in order to resolve the dualism of the judicial review system in Indonesia. Establishing a constitutional review mechanism under a one-roof system can cover the vacuum of legal remedy. In addition, it can prevent inconsistency of interpretations in a judicial review case decided by the Constitutional Court and the Supreme Court. By considering several factors, such as experiences in deciding constitutional review cases, ${ }^{25}$ the numbers of

22 See Article 7 of Law No. 10 of 2004 on the Establishment of Laws and Regulations.

23 See Constitutional Court Decision Number 24/PUU-XI/ 2013 and Number 75/PUU-XII/2014.

24 For further discussion of MPR, see Januari Sihotang and Andy Omara, "Kedudukan Ketetapan Majelis Permusyawaratan Rakyat dalam Undang-Undang Nomor 12 Tahun 2011 dan Implikasi Yuridisnya terhadap Sistem Perundang-Undangan di Indonesia", Jurnal Penelitian Hukum Gadjah Mada, Vol. 1 No. 1 November 2012, Yogyakarta: Fakultas Hukum Universitas Gadjah Mada; Saifudin and Dessy Ariani, "Kajian Yuridis Eksistensi dan Materi Ketetapan Majelis Permusyawaratan Rakyat Republik Indonesia dalam Hirarki Perundang-Undangan di Indonesia", Jurnal Hukum IUS QUIA IUSTUM, Vol. 22 No. 1 January 2015, Yogyakarta: Universitas Islam Indonesia, pages 142-162.

25 At the time of writing, the Constitutional Court has been deciding 879 cases related to the constitutionality of laws since 2003. Additionally, the Constitutional Court Justices have a specific background and expertise in constitutional law. In contrast, the Supreme Court Justices who have diverse backgrounds only examined caseloads that have not been decided, ${ }^{26}$ and the specificity of functions, ${ }^{27} \mathrm{I}$ argue that the Constitutional Court should carry out the review of the constitutionality of all laws and regulations. The addition and transfer of judicial review power from the Supreme Court to the Constitutional Court should be done, ideally, through a Constitutional amendment in order to strengthen its legal and constitutional legitimacy.

$$
\text { Judicial Review System and }
$$

Hierarchy of Laws and Regulations in Indonesia

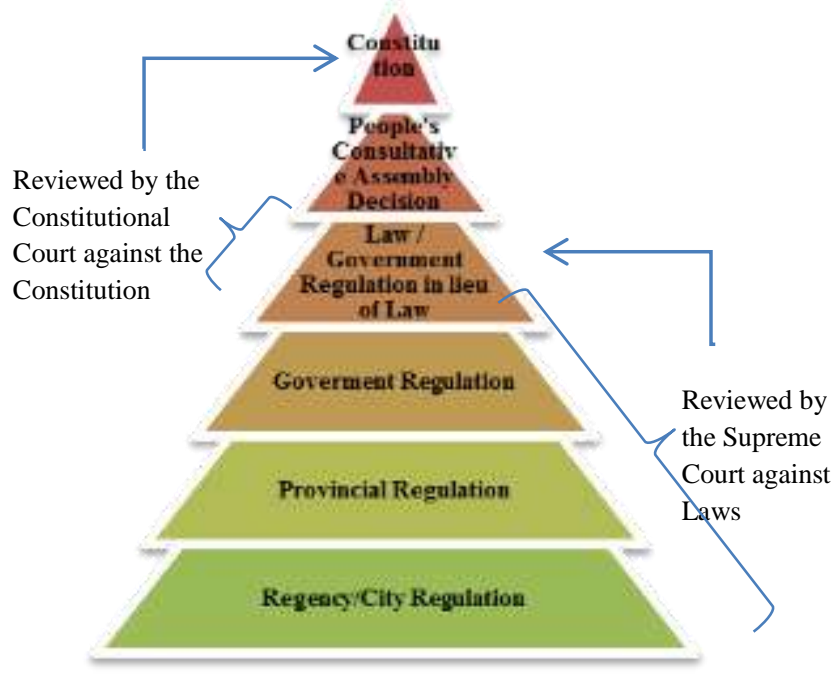

Source: Law No. 12 Year 2011 concerning the Establishment of Laws and Regulations

Furthermore, the need to establish an integrated constitutional review system in the Constitutional Court can also be seen in the Water Resources cases. According to the first decision in the Water Resources (2004) case, ${ }^{28}$ the Constitutional Court declared that the Water Resources Law was conditionally constitutional. This means that the Water Resources Law was constitutional on condition that the implement-

fewer cases related to the legality of regulations and decisions.

26 Up to October 2016, the Constitutional Court only has 90 pending cases, while the Supreme Court still has 5,361 pending cases.

27 The function of the Constitutional Court is more focused on examining cases related to constitutional issues while the Supreme Court, as the highest institution of general courts, examines various types of cases ranging from criminal, civil, religious, military and administrative cases.

28 See Constitutional Court Decision No. 058-059-060-063/ PUU-II/2004 and No. 008/PUU-II/2005. 
ing regulations would be in accordance with the interpretation of the Court. The implementing regulations of the Waters Resources Law were made by the Government in a number of Government Regulations. ${ }^{29}$ In the second decision in the Water Resources (2013) case, ${ }^{30}$ the Constitutional Court indirectly examined relevant Government Regulations, whether it has been in line with the constitutional interpretation and guidelines according to its previous decision, or not. The Court concluded that the Government Regulations did not meet the basic principles and restrictions of water resources management created by the Constitutional Court. This decision clearly shows that the Constitutional Court has reviewed the constitutionality of government regulations. ${ }^{31}$ However, the Court reasoned that the examination did not mean to review the regulations.

According to the Court, the only available way for the Constitutional Court to answer this question is to examine thoroughly the implementing regulations of the Water Resources Law, in this case the government regulations. The Court reasoned that by taking this step it did not mean that the Constitutional Court conducts judicial review of regulations made under any law against such law, but solely because of the requirements of the constitutionality of law which are being reviewed (c.q. the Water Resources Law) are suspended on the obedience of regulations in implementing the Constitutional Court interpretation. ${ }^{32}$

Referring to these cases, an integration of the constitutional review system becomes in-

29 See the Government Regulation No. 16 of 2005 on Development of Water Supply System, the Government Regulation No. 20 of 2006 on Irrigation, the Government Regulation No. 42 of 2008 on Water Resources Management, the Government Regulation No. 42 of 2008 on Groundwater, the Government Regulation No. 38 of 2011 on River and the Government Regulation No. 73 of 2013 on Swamp.

30 See Constitutional Court Decision Number 85/PUU-XI/ 2013.

31 Discussion on the impact of the Constitutional Court Decision on Water Resources (2013) case, see Izzatin Kamala, "Harapan Baru Atas Pengelolaan Sumber Daya Air terkait Putusan MK Nomor 85/PUU-XI/2013", Jurnal Konstitusi, Vol. 12 No. 3, September 2015, Jakarta: Mahkamah Konstitusi Republik Indonesia, pages 422-446.

32 See Constitutional Court Decision Number 85/PUU-XI/ 2013, page 143 para [3.28]. creasingly important. The Water Resources cases show that, although a law does not conflict with the Constitution, its implementing regulations can be contrary to the Constitution. Given that neither the Constitutional Court nor the Supreme Court hold jurisdiction to examine the constitutionality of regulations or decisions, many regulations or decisions considered contrary to Constitution are still implemented today.

In addition, the Water Resources (2013) decision created a new practice of constitutional adjudication in Indonesia, whereby the Constitutional Court can review government regulations indirectly, providing that the related laws, used as the legal basis for making the regulations, have been declared conditionally constitutional or conditionally unconstitutional. This decision also creates jurisprudence for the Court as an entry point to examine the constitutionality of government regulations or decisions in the future.

\section{Conclusion}

Discussion about the need for a constitutional review mechanism in the Indonesian judicial system has been debated since the pre-independence in 1945. However, the idea was rejected because it was considered incompatible with the system and form of Indonesian government at that time. The constitutional review mechanism in Indonesia was formed for the first time in the RIS Constitution, yet there was not a single case of constitutional review lodged to the Supreme Court. The constitutional review mechanism was re-established after the constitutional reform occurred in 1999 to 2002. The Constitutional Court was created to exercise the constitutional review power.

However, there is a problem in the current constitutional review system that places the Constitutional Court in a position that only serves to review the constitutionality of laws against the Constitution, while the Supreme Court merely serves to review the legality of regulations against laws. In other words, there is no mechanism to review the constitutionality of regulations below the level of national law, 
whereas many regulations and executive decisions allegedly violate the Constitution.

\section{Suggestions}

The powers of judicial review granted to the Constitutional Court and the Supreme Court are directly mandated by the Constitution. In the future, these jurisdictions should be integrated to review all laws and regulations against the Constitution in the hands of the Constitutional Court. Thus, consistency of interpretation in dealing with constitutional review cases can be well maintained. The most ideal way to integrate these jurisdictions is to amend the Constitution concerning the judicial powers.

\section{References}

Amaral-Garcia, S., N. Garoupa and V. Grembi. "Judicial Independence and Party Politics in the Kelsenian Constitutional Courts: The Case of Portugal". Journal of Emperical Legal Studies, Vol. 6 No. 2 June 2009. New Jersey: Cornell Law School and Wiley Periodicals;

Bahar, Saafroedin et al. 1995. Risalah Sidang Badan Penyelidik Usaha-Usaha Persiapan Kemerdekaan Indonesia (BPUPKI), Panitia Persiapan Kemerdekaan Indonesia (PPKI) 26 Mei 1945 - 22 Agustus 1945. Jakarta: Sekretariat Negara Republik Indonesia;

Benoit, William and J. D. Agostine. "'The case of the midnight judges' and Multiple Audience Discourse: Chief Justice Marshall and Marbury v. Madison". The Southern Communication Journal, Vol. 59 No. 2. March 1994. Philadelphia: Taylor \& Francis;

Bezemek, Christoph. "A Kelsenian Model of Constitutional Adjudication: The Austrian Constitutional Court". Zeitschrift fur offentliches Recht, Vol. 67. March 2012. Vienna: Springer;

Comella, Victor Ferreres. "The European Model of Constitutional Review of Legislation: Toward decentralization?". ICON-International Journal of Constitutional Law, Vol. 2 No. 3. July 2004. New York: Oxford University Press and New York University School of Law;

Dannemann, Gerhard. "Constitutional Complaints: The European Perspective". The International and Comparative Law Quar- terly, Vol. 43 No. 1 January 1994. Cambridge: Cambridge University Press;

Edwards, R. A. "Bonham's Case: The Ghost in the Constitutional Machine". Denning Law Journal, Vol. 11 No. 1. 1996. Buckingham: University of Buckingham Press;

Faiz, Pan Mohamad. "A Prospect and Challenges for Adopting Constitutional Complaint and Constitutional Question in the Indonesian Constitutional Court". Constitutional Review, Vol. 2 No. 1. May 2016. Jakarta: The Constitutional Court of the Republic of Indonesia;

Garlicki, Lech. "Constitutional Courts versus Supreme Courts". International Journal of Constitutional Law. Vol. 5 No. 1. January 2007. New York: Oxford University Press and New York University School of Law;

Hoesein, Zainal Arifin. 2009. Judicial Review di Mahkamah Agung: Tiga Dekade Pengujian Peraturan Perundang-undangan. Jakarta: RajaGrafindo Persada;

Ihsanuddin. "Komnas Perempuan Minta Presiden Jokowi Hapus 365 Perda yang Diskriminatif". Kompas. 20 March 2015. Available at http://nasional. kompas.com/read/2015/ 03/20/11583441/Komnas.Perempuan.Mint a.Presiden.Jokowi.Hapus.365.Perda.yang. Diskriminatif. Accessed on 10 April 2016;

Kamala, Izzatin. "Harapan Baru Atas Pengelolaan Sumber Daya Air terkait Putusan MK Nomor 85/PUU-XI/2013". Jurnal Konstitusi, Vol. 12 No. 3. September 2015. Jakarta: Mahkamah Konstitusi Republik Indonesia.

Kargaudienè, Aušra. "Individual Constitutional Complaint in Lithuania: Conception and the Legal Issues". Baltic Journal of Law \& Politics. Vol. 4 No. 1. January 2011, Berlin: De Gruyter;

Kelsen, Hans. "Judicial Review of Legislation: A Comparative Study of the Austrian and the American Constitution". Journal of Politics, Vol. 4, May 1942. Chicago: The University of Chicago Press;

Lagi, Sara. "Hans Kelsen and the Austrian Constitutional Court (1918-1929)". Co-herencia. Vol. 9 No. 16. June 2012. Medellín: Universidad EAFIT;

Majelis Permusyawaratan Rakyat Republik Indonesia. 2008. Risalah Rapat ke-36 Panitia Ad Hoc I, Badan Pekerja MPR. Jakarta: Sekretariat Jenderal MPR RI; 
Romeu, Francisco R. "The Establishment of Constitutional Courts: A Study of 128 Democratic Constitutions". Review of Law \& Economic, Vol. 2 No. 6 August 2006. Berlin: De Gruyter;

Saifudin and Dessy Ariani. "Kajian Yuridis Eksistensi dan Materi Ketetapan Majelis Permusyawaratan Rakyat Republik Indonesia dalam Hirarki Perundang-Undangan di Indonesia". Jurnal Hukum IUS QUIA IUSTUM, Vol. 22 No. 1 January 2015. Yogyakarta: Universitas Islam Indonesia;

Sihotang, Januari and Andy Omara. "Kedudukan Ketetapan Majelis Permusyawaratan Rakyat dalam Undang-Undang Nomor $12 \mathrm{Ta}$ hun 2011 dan Implikasi Yuridisnya terhadap Sistem Perundang-Undangan di Indonesia". Jurnal Penelitian Hukum Gadjah Mada, Vol. 1 No. 1. November 2012. Yogyakarta: Fakultas Hukum Universitas Gadjah Mada;

Ülvan, Nazlı Can. "Constitutional Complaint and Individual Complaint in Turkey". Ankara Bar Review. Vol. 6 No. 2. 2013. Ankara: Ankara Bar Association. 